\title{
Suppression of Fusarium Wilt of Watermelon by Soil Amendment with Hairy Vetch
}

X. G. Zhou, University of Maryland, Lower Eastern Shore Research and Education Center, Salisbury 21801; and K. L. Everts, University of Maryland, Lower Eastern Shore Research and Education Center, Salisbury 21801, with joint appointment with the University of Delaware, Georgetown 19947

\begin{abstract}
Zhou, X. G., and Everts, K. L. 2004. Suppression of Fusarium wilt of watermelon by soil amendment with hairy vetch. Plant Dis. 88:1357-1365.

Hairy vetch (Vicia villosa Roth) as a soil amendment was evaluated for suppression of Fusarium wilt of watermelon and soil populations of Fusarium oxysporum f. sp. niveum in greenhouse, microplot, and field studies. When mixed at 1 or $5 \%(\mathrm{wt} / \mathrm{wt})$ in a loamy sand soil that was artificially or naturally infested with race 2 of $F$. oxysporum f. sp. niveum, pulverized dry hairy vetch, crab shell, and urea provided the best suppression (53 to $87 \%$ reduction) of Fusarium wilt on watermelon seedlings among 13 plant and animal residues screened. Soil amended with hairy vetch at 0.25 or $0.5 \%$ (wt/wt) in microplots resulted in 54 to $69 \%$ decreased wilt incidence and 100 to $220 \%$ increase of watermelon plant biomass. Hairy vetch winter cover crop incorporated into field plots under black plastic provided 42 to $48 \%$ reduction of wilt incidence, 64 to $100 \%$ increase of plant biomass, and a 34 to $68 \%$ increase in weight of fruit, comparable to improvements achieved by the soil fumigants methyl bromide or 1,3-dichloropropene plus $35 \%$ chloropicrin. Soil amendment with hairy vetch also increased the sugar content of watermelon fruit 10 to $15 \%$. Significant reductions in the populations of $F$. oxysporum $\mathrm{f}$. sp. niveum were not observed in hairy vetch-amended soil in microplots and field plots, but were observed in greenhouse pot soil amended with $5 \%$ (wt/wt) hairy vetch, which was attributed primarily to increased levels of fungicidal ammonia produced during decomposition. Incorporating hairy vetch into mulched soil can be an alternative or supplement to cultivar resistance and crop rotation for management of Fusarium wilt of watermelon.
\end{abstract}

Additional keywords: Citrullus lanatus

Fusarium wilt of watermelon (Citrullus lanatus (Thunb.) Matsum. \& Nakai), caused by Fusarium oxysporum Schlechtend.:Fr. f. sp. niveum (E. F. Sm.) W. C. Snyder \& H. N. Hans., is among the most important diseases in watermelon production in Maryland and Delaware and in many other parts of the world. As methyl bromide use decreases in response to regulatory action, losses due to Fusarium wilt are expected to increase. A survey conducted in 2000 indicated that $F$. oxysporum f. sp. niveum was distributed widely throughout watermelon-production fields in Maryland and Delaware with the range of inoculum densities from 100 to $1,200 \mathrm{CFU} / \mathrm{g}$ of soil for a majority of the fields (43). The pathogen is able to survive over long periods (10 years or more), once it is established in a field $(2,7,21)$. To date, the disease is best controlled through the use of wilt-resistant cultivars and crop rotations for a minimum of 5 to 7 years

Corresponding author: K. L. Everts

E-mail: keverts@umd.edu

Accepted for publication 17 July 2004.

Publication no. D-2004-1014-02R

(C) 2004 The American Phytopathological Society
$(13,19)$. However, resistance in commercial cultivars often no longer is effective due to the presence of the highly aggressive race 2 of $F$. oxysporum f. sp. niveum (18) and to the increased levels of soil pathogen inoculum (22). Race 2 is present in Delaware $(41,43)$, Florida (20), Oklahoma (3,20), Maryland $(41,43)$, Texas $(18,20)$, and Indiana (D. Egel, personal communication). Most seedless (triploid) cultivars, which represents about $50 \%$ of the watermelon market in the northeastern United States and 30\% in the United States (2), are susceptible to Fusarium wilt $(27,44)$. Most watermelon producers, especially in the areas that are intensively cropped, do not have access to enough land to follow the recommended crop rotation periods. Preplant chemical soil fumigation is a third control option, but it has human and environmental risks, and is costly. Therefore, additional management techniques for commercial watermelon production are needed to control Fusarium wilt of watermelon.

Addition of organic amendments is an effective method of controlling soilborne pathogens and diseases in various fieldcropping systems $(8,14)$. Green residues of Brassica spp., which release fungitoxic isothiocyanates during decomposition, effectively suppressed several diseases, including those caused by $F$. oxysporum $\mathrm{f}$. sp. conglutinans in cabbage $(29,30)$, Verticillium dahliae in cauliflower (35), and Aphanomyces euteiches in pea (24). By producing fungicidal ammonia $(34,38)$, cottonseed, linseed, and soybean amendments reduced soil populations of $F$. $o x$ ysporum and $F$. solani $(39,40)$, and urea inhibited soilborne pathogens as diverse as Fusarium spp. (33), Pythium spp. (6), Thielaviopsis basicola (6), and Macrophomina phaseolina (6). A formulated soil amendment containing urea and oyster shells inhibited germination of chlamydospores of $F$. oxysporum f. sp. niveum and controlled the severity of Fusarium wilt in watermelon in the field (36). The suppressive effects of organic amendments on diseases are primarily associated with a reduction in pathogen inoculum density in amended soils $(6,14,29,30,35,36,39,40)$.

Hairy vetch (Vicia villosa Roth) is a legume that can be planted as a winter cover crop (1). Hairy vetch acreage has increased in the Mid-Atlantic region of the United States because it reduces soil erosion, decreases nutrient runoff, and maintains soil productivity. Incorporation of a hairy vetch cover crop in field soil reduced soil populations of T. basicola, and the incidence of black root rot caused by the pathogen on cotton $(5,31)$. The suppressive effect was attributed to the production of ammonia in amended soil (4). A killed hairy vetch cover crop, when left on the soil surface as an organic mulch, reduced some foliar or fruit diseases on pumpkin (10) and tomato (23).

The objectives of this work were to (i) screen organic amendments of plant residues and animal wastes for suppression of Fusarium wilt of watermelon in the greenhouse; (ii) evaluate the effect of hairy vetch amendment rate on the incidence of Fusarium wilt and soil population of $F$. oxysporum f. sp. niveum in field microplots; and (iii) examine the effectiveness of soil incorporation of hairy vetch winter cover crop in wilt suppression, pathogen reduction, plant growth promotion, and yield increase compared with commercially used preplant soil fumigants in the field. Preliminary reports of this work have been published $(42,45,46)$.

\section{MATERIALS AND METHODS}

Soils. Norfolk 'A' loamy sand (sand, 82 to $83 \%$; silt, $7 \%$; clay, 10 to $11 \%$; pH 5.8 
to 7.3 , organic matter, 0.8 to $1.2 \%$; waterholding capacity [WHC], 174 to 200 $\mathrm{ml} / \mathrm{kg}$ ) located at or collected from fields at the University of Maryland Lower Eastern Shore Research and Education Center (UM-LESREC), Salisbury, MD, was used in this study. All soils collected for greenhouse experiments were passed through a 2.38-mm screen to remove large organic residues before use.

Fungal strains. Unless stated otherwise, a race 2 isolate (F-17B-R-2) of $F$. oxysporum f. sp. niveum, obtained from a wilted watermelon plant in Maryland in a previous study (43), and its derived, chlorate-resistant marked strain were used. The chlorate-resistant strain (F-17B-R-2-C) of the pathogen was generated using a procedure described previously (28), and it had characteristics similar to those of the wildtype isolate in pathogenicity, growth on potato dextrose agar (PDA), and growth in soil. Both strains were maintained in a mixture of perlite and sandy soil (1:2, $\mathrm{wt} / \mathrm{wt})$ at $4^{\circ} \mathrm{C}$.

Inocula. A liquid mineral salts inoculum was produced by transferring several soil particles from a soil-tube culture of the isolate F-17B-R-2 of $F$. oxysporum f. sp. niveum into a liquid mineral salts medium (25). The culture was incubated on an orbital shaker at $128 \mathrm{rpm}$ at room temperature for 8 to 10 days, then homogenized in a blender for $2 \mathrm{~min}$ and filtered through eight layers of cheesecloth. The inoculum was adjusted to the desired concentration with the aid of a Spencer hemacytometer, and used to infest soil for greenhouse experiments.

To produce the chlorate-resistant marked isolate inoculum used to infest field microplots, a wheat flour:perlite:sand medium was inoculated with a culture of the chlorate-resistant marked isolate of $F$. oxysporum f. sp. niveum. The wheat flour:perlite:sand medium was prepared by mixing wheat flour, $9 \mathrm{~kg}$; perlite, $3 \mathrm{~kg}$; sandy soil, $60 \mathrm{~kg}$; and distilled water, $9 \mathrm{~kg}$. Before mixing, soil and perlite portions were autoclaved separately at $121^{\circ} \mathrm{C}$ for 2 $\mathrm{h}$. The mixture medium was packaged into heat-resistant plastic bags of $8 \mathrm{~kg}$ each. Each opening of the bags was gathered around a large cotton plug $(6 \mathrm{~cm}$ in diameter) in which a copper tube $(4 \mathrm{~cm}$ in diameter) with an air-exchangeable cotton plug had been inserted. Each part was tied securely with a thread. After autoclaving at $121^{\circ} \mathrm{C}$ for $1 \mathrm{~h}$ and cooling, the medium in each bag was infested aseptically with 400 $\mathrm{ml}$ of conidial suspension $\left(5 \times 10^{6}\right.$ microconidia $/ \mathrm{ml}$ ) of a 4-day-old culture of the chlorate-resistant marked isolate of $F$. oxysporum $\mathrm{f}$. sp. niveum. The infested medium was mixed thoroughly by turning over the bags several times, and the bags were inflated aseptically by blowing filtered air through an inserted plastic pipette into them. This operation occurred twice a week until the end of a 3-week incubation period at room temperature. The infested medium was placed in large containers and allowed to air dry for 10 days. The dried culture was ground and passed through a 1.7-mm screen before use.

Greenhouse tests. Two types of soil were prepared to provide a broad test: soil A, a soil artificially infested with race 2 of F. oxysporum f. sp. niveum; and soil $\mathrm{B}$, a soil naturally infested with $F$. oxysporum $\mathrm{f}$. sp. niveum. Soil A was obtained by mixing $40 \mathrm{~kg}$ of soil with a $1,000-\mathrm{ml}$ liquid mineral salts inoculum $\left(10^{5}\right.$ microconidia/ml $)$ from a race 2 isolate culture of $F$. $o x$ ysporum f. sp. niveum prepared as described before. The infested soil was incubated in plastic bags with filtered air exchange at room temperature for more than 6 weeks to stimulate the formation of chlamydospore inoculum. The soil was obtained from a noncultivated land cropped to the nonhost fescue grass (Festuca sp.) for more than 15 years and contained low levels (about $25 \mathrm{CFU} / \mathrm{g}$ of soil) of $F$. oxysporum when assayed by soil dilution plating on Komada's medium (17). Soil B was obtained from a long-term watermelon research field that was naturally infested with $F$. oxysporum f. sp. niveum comprising a mixture of races 0,1 , and 2 , with race 2 being the predominant population (43).

Thirteen kinds of plant residues, animal wastes, urea, and $\mathrm{CaCO}_{3}$ (Table 1) were singly incorporated at the rates of 0,1 , or $5 \%$ (wt/wt, dry soil equivalent) into soils A or B. Low rates of 0.1 or $0.5 \%$ were used for chitin, $\mathrm{CaCO}_{3}$, and urea. The fescue grass-cropped soil that received neither Fusarium inoculum nor organic matters, or that did not receive Fusarium inoculum but was amended individually with organic matters, served as the control treatments. Treatments were arranged in a randomized complete-block design.

Corn, hairy vetch, soybean, watermelon, and wheat residues comprised mature stems and leaves collected from field plots at the UM-LESREC. Chicken manure, pine sawdust, and tree branches from yard wastes (unknown proportion of tree species) were obtained locally and composted before use. Crab shell and oyster shell were byproducts of aquaculture from the Chesapeake Bay. Chitin, $\mathrm{CaCO}_{3}$, and urea were obtained from Sigma-Aldrich (St. Louis). All plant and animal materials were air dried under the sunlight in a greenhouse for at least 6 weeks, and ground with a Wiley mill through a 1-mmdiameter screen.

The equivalent of $200 \mathrm{~g}$ of dry amended or nonamended soil was placed in each plastic pot $(7 \mathrm{~cm}$ in diameter) with no drainage holes. There were three replicate pots for each treatment. To maintain soil moisture and allow aeration, the open end of each pot was covered with a transparent plastic film that had six 1-mm-diameter pores. The soil was maintained at $50 \%$ of
WHC during incubation by weighing and watering the pots every 3 days. All pots were kept at $24 \pm 0.5^{\circ} \mathrm{C}$ in a growth chamber with a daily 12-h florescent light period.

At 7 days after amendment, a 5-g (dry weight basis) soil sample was removed from each pot, placed in $5 \mathrm{ml}$ of water, incubated for $30 \mathrm{~min}$, stirred, and $\mathrm{pH}$ measured with a handheld $\mathrm{pH}$ meter. The concentration of ammonia in the headspace of each pot also was measured using a modification of the method described by Candole and Rothrock (4). Ammonium was trapped in a $5 \mathrm{ml}$ solution of $2 \%$ boric acid in small vials, covered with two layers of cheesecloth, which were placed under polyethylene for $24 \mathrm{~h}$. The ammonia-containing solutions were tested with appropriate ranges $(0.1$ to $1,000 \mathrm{ppm})$ of VACUettes ammonia kits (CHEMetrics, Inc., Calverton, VA). At 28 days after amendment, a 5-g (dry weight equivalent) soil sample, comprising three subsamples taken from each pot, was serially diluted with $0.1 \%$ sterilized water agar, and $1-\mathrm{ml}$ aliquots of the resulting suspensions were plated on Komada's medium. There were six plates for each treatment. The proportion of pathogenic to nonpathogenic colonies on these plates was determined by greenhouse pathogenicity bioassays using a procedure described before (43). All colonies were tested when the total number of colonies of $F$. oxysporum on all plates for a treatment was $\leq 30$; otherwise, 30 colonies were selected randomly when the total number of colonies was $>30$. The average of adjusted counts on the six plates was used as the population density of $F$. oxysporum $\mathrm{f}$. sp. niveum for each treatment.

After a 4-week fallow period, amended and nonamended soils were individually transferred into autoclaved heat-resistant plastic pots ( 60 by 60 by $100 \mathrm{~mm}$ ), and six 2-week-old seedlings of the wilt-susceptible watermelon cv. Sugar Baby were transplanted into each pot. There were three replicate pots for each treatment. All plants were maintained at 20 to $31^{\circ} \mathrm{C}$ in a greenhouse. Counts of wilted or dead seedlings were made twice a week until 5 weeks after transplanting, the time at which few additional seedlings became wilted. The experiment was conducted twice.

Microplot tests. To evaluate the suppressiveness of hairy vetch soil amendment under simulated field conditions, fiberglass microplots (delineated by collars $76 \mathrm{~cm}$ in diameter and $61 \mathrm{~cm}$ deep) were used to conduct two independent experiments from May to September in 2001 and 2002. All microplots were placed in rows and spaced $2 \mathrm{~m}$ apart on all sides, with approximately a $6-\mathrm{cm}$ lip above the soil level. Black plastic films were laid on the ground between microplots to prevent weed growth.

Microplots were infested with $F$. $o x$ ysporum f. sp. niveum by incorporating 
350 or 300 g (in 2001 or 2002, respectively) of inoculum per microplot of the chlorate-resistant marked isolate to a depth of $20 \mathrm{~cm}$. This depth was used because more than $81 \%$ of the population of $F$. oxysporum in a naturally infested watermelon field was distributed within this range in a preliminary evaluation of vertical distribution (unpublished data). This also was the depth that contained more than $94 \%$ of propagules of $F$. oxysporum $\mathrm{f}$. sp. conglutinans in a recently infested cabbage field (29). The microplots were newly established within the field, to which no watermelon had been cropped for more than 10 years. Prior to pathogen infestation, soil dilutions on Komada's medium and greenhouse pathogenicity bioassays did not detect the pathogen. After incorporation of the chlorate-resistant marked isolate culture, the soil was mixed thoroughly with a rake and left for 3 to 4 weeks until the addition of hairy vetch.
In June of 2001, hairy vetch (dry green material ground through a $1-\mathrm{mm}$ screen) was incorporated at $0,0.5$, or $1 \%(\mathrm{wt} / \mathrm{wt})$ into the upper $20 \mathrm{~cm}$ of soil. All microplots were irrigated to field capacity. Each microplot was covered with a durable black plastic film secured on all sides by soil outside the microplot. Microplots that received neither Fusarium inoculum nor hairy vetch also were included to evaluate background disease incidence. Treatments were arranged in a randomized completeblock design with four replicates. At intervals of $0,3,7,14$, and 28 days after amendment, soil samples of about $100 \mathrm{~g}$ comprising three subsamples from each microplot were evaluated. A 10-g (dry weight equivalent) soil subsample was serially diluted with $0.1 \%$ sterilized water agar, and 1-ml aliquot of the resulting suspensions was distributed onto each of two plates filled with the chlorate-containing selective medium (12) MMCPA (minimal medium amended with $\mathrm{KClO}_{3}$ at $7.5 \mathrm{~g} /$ liter and supplemented with pentachloronitrobenzene [0.5 $\mathrm{g}$ a.i./liter], chloramphenicol [250 mg/liter], and 85\% lactic acid [0.6 $\mathrm{ml} /$ liter]) for growth of chlorate-resistant mutants. The average of the eight plates was used to determine the population density of $F$. oxysporum f. sp. niveum for each treatment. Soil temperatures at a depth of 5 $\mathrm{cm}$ under plastic film were monitored.

At 28 days after hairy vetch amendment, the plastic films were removed, the soil was mixed thoroughly, and 15 4-week-old seedlings of the watermelon cv. Sugar Baby were transplanted into each microplot. Insects and foliar diseases were managed with applications of recommended pesticides. All plots were fertilized weekly with a total of about $11 \mathrm{~g}$ of 20-2020 (N-P-K) and overhead irrigated with water as needed. Development of Fusarium wilt was monitored weekly, and plants that had one or more runners wilted

Table 1. Incidence of Fusarium wilt of watermelon, population (pop.) densities of Fusarium oxysporum f. sp. niveum, soil pH, and ammonia levels in each of two types of soil after amending with hairy vetch and 12 other amendments at $1 \mathrm{or} 5 \%(\mathrm{wt} / \mathrm{wt})$ in greenhouse experiments

\begin{tabular}{|c|c|c|c|c|c|c|c|c|}
\hline \multirow[b]{2}{*}{ Soil, amendment ${ }^{w}$} & \multicolumn{4}{|c|}{$1 \%(\mathrm{wt} / \mathrm{wt})^{\mathrm{v}}$} & \multicolumn{4}{|c|}{$5 \%(w t / w t)^{v}$} \\
\hline & $\begin{array}{c}\text { Wilt \% } \\
(\text { reduction \% })^{\mathbf{x}}\end{array}$ & $\begin{array}{l}\text { Pop. density } \\
(\text { reduction \% })^{\mathrm{y}}\end{array}$ & $\begin{array}{l}\text { Soil } \\
\mathbf{p H}^{\mathbf{z}}\end{array}$ & $\begin{array}{c}\text { Ammonia } \\
(\mathbf{p p m})^{\mathrm{z}}\end{array}$ & $\begin{array}{c}\text { Wilt \% } \\
(\text { reduction \% })^{x}\end{array}$ & $\begin{array}{l}\text { Pop. density } \\
(\text { reduction \% })^{y}\end{array}$ & $\begin{array}{l}\text { Soil } \\
\text { pH }^{z}\end{array}$ & $\begin{array}{c}\text { Ammonia } \\
(\mathbf{p p m})^{\mathrm{z}}\end{array}$ \\
\hline \multicolumn{9}{|l|}{ Soil A } \\
\hline Nonamended control & $94(0)$ & $3.3(0)$ & 6.5 & 0.3 & $94(0)$ & $3.3(0)$ & 6.5 & 0.3 \\
\hline Watermelon & $89(5)$ & $3.3(0)$ & 7.1 & 3 & $100(-6)$ & $4.0(-21)$ & 7.5 & 10 \\
\hline Hairy vetch & $44(53)^{*}$ & $3.1(6)$ & 7.2 & 15 & $28(70)^{*}$ & $0.7(78)^{*}$ & 8.9 & 152 \\
\hline Urea (low) & $44(53)^{*}$ & $0.0(100)^{*}$ & 8.9 & 170 & $17(82)^{*}$ & $0.0(100)^{*}$ & 8.9 & 650 \\
\hline Crab shell & $39(59) *$ & $0.0(100)^{*}$ & 9.0 & 405 & $0(100)^{*}$ & $0.0(100)^{*}$ & 8.9 & 675 \\
\hline Chicken manure & $56(40)^{*}$ & $3.1(6)$ & 6.9 & 16 & $83(12)$ & $3.4(-3)$ & 7.4 & 25 \\
\hline $\mathrm{CaCO}_{3}$ (low) & $67(29)$ & $2.8(15)$ & 7.2 & 1 & $94(0)$ & $1.8(45)^{*}$ & 7.8 & 1 \\
\hline Chitin (low) & $83(12)$ & $3.3(0)$ & 6.4 & 5 & $94(0)$ & $3.6(-9)$ & 7.1 & 8 \\
\hline Corn & $61(35)^{*}$ & $3.4(-3)$ & 6.5 & 15 & $83(12)$ & $3.7(-12)$ & 6.9 & 18 \\
\hline Oyster shell & $83(12)$ & $1.7(48)^{*}$ & 7.6 & 20 & $78(17)$ & $1.7(48)^{*}$ & 8.1 & 25 \\
\hline Pine sawdust & $67(29)$ & $3.4(-3)$ & 7.0 & 5 & $94(0)$ & $1.9(42)^{*}$ & 7.5 & 45 \\
\hline Soybean & $61(35) *$ & $4.0(-21)$ & 6.9 & 25 & $78(17)$ & $3.7(-12)$ & 8.1 & 50 \\
\hline Wheat & $94(0)$ & $3.2(3)$ & 6.4 & 5 & $94(0)$ & $4.1(-24)$ & 7.1 & 15 \\
\hline Tree branches & $56(40)^{*}$ & $3.2(3)$ & 6.7 & 4 & $89(5)$ & $3.5(-6)$ & 7.4 & 10 \\
\hline \multicolumn{9}{|l|}{ Soil B } \\
\hline Nonamended control & $83(0)$ & $2.5(0)$ & 7.2 & 0.4 & $83(0)$ & $2.5(0)$ & 7.2 & 0.4 \\
\hline Watermelon & $94(-13)$ & $3.4(-36)$ & 7.3 & 4 & $100(-20)$ & $3.8(-52)$ & 7.8 & 15 \\
\hline Hairy vetch & $11(87)^{*}$ & $2.4(4)$ & 7.1 & 18 & $11(87)^{*}$ & $0.8(66)^{*}$ & 8.9 & 140 \\
\hline Urea (low) & $28(66) *$ & $0.0(100)^{*}$ & 9.0 & 163 & $0.0(100)^{*}$ & $0.8(66) *$ & 9.0 & 520 \\
\hline Crab shell & $11(87)^{*}$ & $0.0(100)^{*}$ & 8.8 & 450 & $0.0(100)^{*}$ & $0.0(100)^{*}$ & 9.0 & 625 \\
\hline Chicken manure & $61(27)$ & $2.5(0)$ & 7.4 & 21 & $78(6)$ & $3.0(-20)$ & 7.8 & 35 \\
\hline $\mathrm{CaCO}_{3}$ (low) & $78(6)$ & $1.1(57)^{*}$ & 7.6 & 5 & $83(0)$ & $1.7(32)$ & 8.0 & 8 \\
\hline Chitin (low) & $72(13)$ & $2.5(0)$ & 6.8 & 12 & $56(33)$ & $2.9(-16)$ & 7.7 & 15 \\
\hline Corn & $33(60) *$ & $3.3(-32)$ & 7.1 & 25 & $17(80)^{*}$ & $1.3(49)^{*}$ & 7.2 & 60 \\
\hline Oyster shell & $67(19)$ & $1.6(36)$ & 7.8 & 25 & $28(66)^{*}$ & $1.6(36)$ & 8.5 & 30 \\
\hline Pine sawdust & $55(34)$ & $2.9(-16)$ & 7.3 & 7 & $50(40)$ & $3.3(-32)$ & 8.0 & 10 \\
\hline Soybean & $61(27)$ & $3.2(-28)$ & 7.4 & 65 & $83(0)$ & $3.7(-48)$ & 7.6 & 80 \\
\hline Wheat & $28(66) *$ & $1.6(36)$ & 7.0 & 16 & $44(47)^{*}$ & $2.7(-8)$ & 7.7 & 25 \\
\hline Tree branches & $83(0)$ & $1.8(28)$ & 7.4 & 15 & $72(13)$ & $3.0(-20)$ & 7.8 & 25 \\
\hline
\end{tabular}

${ }^{\mathrm{v}}$ Positive and negative values in parentheses represent percent reduction and percent increase in percent wilt or population density, respectively, compared with the nonamended control. Means followed by an asterisk $(*)$ in a column within the same type of soil represent a significant difference $(P \leq 0.05)$ from the nonamended control according to Fisher's protected least significant difference test. Percent wilt data were analyzed after transformation to the arcsine of the square root of the proportion of wilt. All control seedlings grown in soil that received neither Fusarium inoculum nor amendments, or that did not receive Fusarium inoculum but were amended individually with organic matters had no symptoms of Fusarium wilt and are not presented in the table.

${ }^{\text {w }}$ Soil A was a nonhost fescue grass-cropped soil that was artificially infested with a race 2 culture of $F$. oxysporum f. sp. niveum; and soil B was a long-term watermelon research field soil that was naturally infested with $F$. oxysporum f. sp. niveum primarily consisting of race 2 (43). All plant-derived materials comprised mature stems and leaves. The rate for chitin, $\mathrm{CaCO}_{3}$, or urea was 0.1 and $0.5 \%$ (wt/wt).

${ }^{x}$ Average percentage of wilt-susceptible 'Sugar Baby' watermelon (six plants/pot, three pots/amendment) that were wilted or dead 5 weeks after transplanting.

${ }^{y}$ Soil population densities were $\log _{10}(\mathrm{CFU} / \mathrm{g}$ of soil +1$)$ transformed. Population densities were determined 4 weeks after amendment (prior to transplanting), and were estimated by soil dilution plating on Komada's medium and adjusted by additional greenhouse pathogenicity bioassays of randomly selected representative colonies of $F$. oxysporum.

${ }^{\mathrm{z}}$ Determined 1 week after amendment. 
or dead were counted 45 days after transplanting. At the end of the experiment, the length of the primary runners of three randomly selected plants per microplot was measured, and three plants per microplot were cut at the soil line and brought into a greenhouse to air dry for 6 weeks in order to estimate the dry weight of aboveground plant biomass. The experiment was conducted twice in 2001. The second experiment was conducted in additional microplots 2 weeks after initiation of the first one.

In 2002, the same microplots were used; however, all microplots were replaced with new soil from the field, and reinfested with the chlorate-resistant marked isolate culture of F. oxysporum f. sp. niveum. The $1 \%$ amendment rate of hairy vetch was slightly toxic to watermelon seedlings in the 2001 experiments; therefore, the rate was decreased fourfold to $0.25 \%$. The percentage of wilted plants and the measurements for plant growth were determined 51 days after transplanting. At maturity, all fruit were harvested and total yield of fruit (most of them unmarketable) measured. All other procedures were the same as the 2001 experiments.

Field tests. To verify the effectiveness of hairy vetch under field conditions and compare its efficacy to commercially used chemical soil fumigants, field plot experiments were conducted in 2002 and 2003. The plots were established in a field at the UM-LESREC. The plot area had a history of Fusarium wilt in watermelon. All plots were single raised beds $25 \mathrm{~m}$ long, $0.9 \mathrm{~m}$ wide, and $15 \mathrm{~cm}$ high. Plots were separated by fallow areas about $1 \mathrm{~m}$ apart between hairy vetch and non-hairy vetch plots and $4 \mathrm{~m}$ apart between replicated blocks.

In 2002, three treatments were evaluated: nontreated control (winter fallow), 1,3-dichloropropene plus $35 \%$ chloropicrin $(1,3-D+C)$, and hairy vetch winter cover crop. Treatments were arranged in a randomized complete-block design with four replicates. Hairy vetch seed inoculated with a commercial preparation of Rhizobium spp. were sown to plots at $50 \mathrm{~kg} / \mathrm{ha}$ in early October 2001. The plots received no irrigated water, fertilizers, pesticides, or any other treatment until hairy vetch was incorporated into the soil in June 2002. Hairy vetch samples in three areas $(0.5$ by $0.5 \mathrm{~m}$ ) at the edges of each plot were collected and the amount of aboveground biomass (dry weight) was estimated. Hairy vetch was flattened with a cultipacker, sprayed with Paraquat (Gramoxone Extra $2.5 \mathrm{SC}, 1.2 \mathrm{~kg}$ a.i./ha), disked three times, and incorporated to a depth of 15 to $20 \mathrm{~cm}$ with a tractor-mounted rototiller. Plot beds were formed by a bed shaper, a single drip irrigation tube was placed at the center, and the beds were covered with black polyethylene. The winter fallow plot area received the same bed preparation as the hairy vetch treatment. Because soil tests indicated that no $\mathrm{P}$ or $\mathrm{K}$ was needed, 18-0$5 \mathrm{~N}-\mathrm{P}-\mathrm{K}$ at $398 \mathrm{~kg} / \mathrm{ha}$ was applied to each plot before bedding. The preplant soil fumigant 1,3-D + C (Telone C35; Dow AgroScience, Indianapolis, IN) was chisel injected to a $20-\mathrm{cm}$ soil depth in the winter fallow plots at 327 liter/ha, and covered immediately with black polyethylene. All plots were irrigated to field capacity. At intervals of $0,1,2$, and 4 weeks after hairy vetch incorporation, approximately 200-g soil samples comprising three subsamples taken from each plot were evaluated. A 10g (dry weight equivalent) subsample was serially diluted with $0.1 \%$ sterilized water agar and a 1-ml aliquot of the resulting suspensions was placed onto each of two plates filled with Komada's medium. The proportion of pathogenic to nonpathogenic colonies on these plates was determined as described previously for greenhouse soil samples. The average of adjusted counts on eight plates was used as the population of $F$. oxysporum f. sp. niveum for each treatment.

After a fallow period of approximately 4 weeks, 4-week-old seedlings of the watermelon cv. Sangria (moderately susceptible to race 1 of $F$. oxysporum $\mathrm{f}$. sp. niveum) were transplanted $0.91 \mathrm{~m}$ apart within rows on 5 July. Irrigation and management of foliar diseases, insects, and weeds were conducted according to local extension recommendations. Development of Fusarium wilt was monitored weekly. Incidence was determined 56 days after transplant by counting plants that had one or more runners wilted or dead. The length of the primary runners of three plants per plot was measured 21 days after transplant. At maturity, marketable fruit were individually weighed, and sugar content of three randomly selected fruit per plot was measured with a handheld refractometer. Three plants per plot were cut at the soil line and brought into a greenhouse to air dry for 6 weeks, and the dry weight of aboveground plant biomass estimated.

In 2003, the same field was used; however, methyl bromide was included for comparison. To evaluate if there is an additional effect of the fumigant in combination with hairy vetch soil amendment, a treatment of hairy vetch with methyl bromide also was added in a split-plot design with cover crop as the main plot and fumigant as the subplot. Hairy vetch was seeded in early October 2002 and incorporated into soil on 20 May. In late May, 180-5 N-P-K at $373 \mathrm{~kg} / \mathrm{ha}$ was applied to each plot before bedding. Methyl bromide (98\% a.i. formulation, Terr-O-Gas 98; Great Lakes Chemical Corp., West Lafayette, IN) at $224 \mathrm{~kg} / \mathrm{ha}$ was injected to a 20 $\mathrm{cm}$ soil depth in winter fallow plots or hairy vetch-incorporated plots, and covered immediately with black polyethylene. Seedlings of the same watermelon cv. Sangria were transplanted on 26 June. The percentage of wilted plants was evaluated 60 days after transplanting. All other procedures (soil inoculum density determination and plant growth and fruit measurements) were the same as the 2002 experiment.

Data analyses. All data were analyzed by the GLM procedure of the Statistical Analysis System (version 8.0; SAS Institute, Cary, NC). All experiments were analyzed as a randomized complete-block design except the 2003 field experiment, which was analyzed as a split-plot design. Data were subjected to analysis of variance (ANOVA) and means were separated by Fisher's protected least significant difference (LSD) test at $P \leq 0.05$. Linear regression procedures were performed to determine the significant and strength of the relationship between soil $\mathrm{pH}$ and ammonia level, and between ammonia level and pathogen density. To normalize variances, percent wilt data were transformed to the arcsine of the square root of the proportion of wilt and CFU of $F$. oxysporum $\mathrm{f}$. sp. niveum transformed to $\log _{10}(\mathrm{CFU} / \mathrm{g}+1)$. When an interaction between amendment treatments and year or experiment was present, the data for each year or experiment are presented separately.

\section{RESULTS}

Greenhouse tests. The addition of hairy vetch, urea, or crab shell at either rate provided the best wilt suppression of 13 amendments screened in soil artificially (soil A) or naturally (soil B) infested with F. oxysporum f. sp. niveum (Table 1). Wilt reduction by hairy vetch ranged from 53 to $87 \%$ compared with the nonamended control. A significant reduction in soil propagules of $F$. oxysporum f. sp. niveum by hairy vetch was not observed at $1 \%$ (wt/wt), but was observed at 5\%. However, slight damage to the roots of some seedlings at $5 \%(\mathrm{wt} / \mathrm{wt})$ was evident. Soil amendment with urea or crab shell at either rate significantly reduced or completely eliminated detectable populations of $F$. oxysporum f. sp. niveum in the soil. Pathogenicity assays of randomly selected $F$. oxysporum colonies indicated that there were no differences $(P \geq 0.05)$ in the percentage of $F$. oxysporum populations that were pathogenic in nonamended soil and soils mixed with hairy vetch and urea, with the pathogenic percentage ranging from 47 to $71 \%$ (data not shown). The suppressive effects of 10 other amendments, including composted chicken manure, on the incidence of Fusarium wilt and population densities of F. oxysporum f. sp. niveum were inconsistent or insignificant (Table 1).

At 7 days after amendment of soils A or $\mathrm{B}$, hairy vetch at $1 \%$ caused no or slight increase in soil $\mathrm{pH}$, but at $5 \%$ caused $\mathrm{pH}$ to increase to 8.9 (Table 1). The concentrations of ammonia detected in the headspaces of soil amended with hairy vetch at 
$1 \%$ were low and at $5 \%$ were high. Urea and crab shell at both rates caused the greatest increase in soil $\mathrm{pH}$ and ammonia among the 13 amendments evaluated. Overall, there was a trend toward increasing ammonia concentration with increasing $\mathrm{pH}$ in amended soils. A close regression relationship between soil $\mathrm{pH}(X)$ and ammonia concentration $(Y)$ was observed: $Y=$ $\exp ^{(1.7 \mathrm{X}-9.9)}, R^{2}=0.58, P<0.0016$ at $1 \%$ amendments in soil A; $Y=\exp ^{(2.2 \mathrm{X}-13.9)}, R^{2}$ $=0.63, P<0.0006$ at $5 \%$ amendments in soil A; $Y=\exp ^{(1.7 \mathrm{X}-10.2)}, R^{2}=0.44, P<$ 0.0102 at $1 \%$ amendments in soil B; and $Y$ $=\exp ^{(2.1 \mathrm{X}-13.5)}, R^{2}=0.49, P<0.0051$ at $5 \%$ amendments in soil B.

Regression analyses also indicated a close relationship between ammonia level and pathogen density in these amended soils. Soil populations of $F$. oxysporum $\mathrm{f}$. sp. niveum $(Y)$ linearly decreased with an increase in ammonia $(X): Y=-0.0094 X+$ $3.161, R^{2}=0.70, P<0.0002$ at $1 \%$ amendments in soil A; $Y=-0.0005 X+3.129, R^{2}$ $=0.61, P<0.0009$ at $5 \%$ amendments in soil A; $Y=-0.0062 X+2.42, R^{2}=0.44, P<$ 0.0093 at $1 \%$ amendments in soil B; and $Y$ $=-0.0042 X+2.703, R^{2}=0.51, P<0.0043$ at $5 \%$ amendments in soil B.

Soils amended with $1 \%$ hairy vetch induced a consistent suppression of Fusarium wilt; therefore, amendment rates of hairy vetch $\leq 1 \%$ were used for further work.

Microplot tests. Hairy vetch amended into microplots at rates as low as $0.25 \%$ (wt/wt) was effective in suppression of Fusarium wilt and improvement of plant growth (Table 2). In either experiment in 2001 , hairy vetch at 0.5 or $1 \%$ reduced wilt incidence by 62 to $82 \%$, increased the length of primary runners of plants by 53 to $94 \%$, and increased aboveground plant biomass by 100 to $209 \%$. No significant differences $(P \leq 0.05)$ in these measurements were observed between the two rates evaluated. Minor signs of phytotoxicity were observed following 4 days of transplanting on some seedlings in microplots amended with $1 \%$ hairy vetch. In either experiment in 2002, when the rate was further reduced to $0.25 \%$, hairy vetch still decreased the percentage of wilted plants by 54 to $62 \%$, increased the length of primary runners of plants by 35 to $46 \%$, increased aboveground plant dry weight by 135 to $167 \%$, and doubled total fruit yield, achieving almost the same effectiveness as was obtained from $0.5 \%$ (Table 2).

However, there were no significant reductions in numbers of $F$. oxysporum f. sp. niveum in soils amended with 0.25 or $0.5 \%$ hairy vetch (Fig. 1). In the 2001 experiments, soil populations were slightly reduced by $0.5 \%$ hairy vetch from 7 to 28 days after amendment, but were not statistically significant $(P \geq 0.05)$ from the nonamended control. When the rate was increased to $1 \%$, significant reductions were observed. In the 2002 experiments, there were no observed reductions $(P \geq$ $0.05)$ in population densities of $F$. $o x$ ysporum f. sp. niveum in soils mixed with 0.25 and $0.5 \%$ hairy vetch throughout a 4 week incubation period compared with the nonamended control.

In 2001, the average maximum temperatures at the $5-\mathrm{cm}$ depth in nonamended microplots covered with plastic film were 32.1 and $33.2^{\circ} \mathrm{C}$ for experiments 1 and 2 , respectively. In plots amended with $1 \%$ hairy vetch, the average maximum temperatures were 33.4 and $35.7^{\circ} \mathrm{C}$ for experiments 1 and 2 , respectively. Soil temperatures in 2002 were not monitored.

Field tests. After incorporation of hairy vetch winter cover crop into field plots, Fusarium wilt was reduced, vine length and shoot dry weight increased, and fruit yield and sugar content increased in both years (Table 3). In 2002, aboveground hairy vetch biomass was estimated at 4.7 to $5.9 \mathrm{t} / \mathrm{ha}$ (dry weight equivalent), with an average of $5.2 \mathrm{t} / \mathrm{ha}$, which corresponded to about $0.20 \%$ of hairy vetch amended into a depth of $20 \mathrm{~cm}$. The percentage of wilted plants was reduced $48 \%$ following the incorporation of hairy vetch compared with the winter fallow treatment (nontreated control), the same degree of reduction as that achieved by the fumigant 1,3-D + C (Table 3). Hairy vetch and 1,3-D $+\mathrm{C}$ provided 64 and $106 \%$ increase of aboveground plant biomass and 34 and $50 \%$ increase of marketable fruit yield, respectively. Hairy vetch also increased

Table 2. Incidence of Fusarium wilt, plant growth, and total fruit yield of watermelon in field microplots amended with various rates of hairy vetch in each of two experiments in 2001 and 2002

\begin{tabular}{|c|c|c|c|c|c|}
\hline \multirow[b]{2}{*}{$\begin{array}{l}\text { Year, } \\
\text { experimenty }\end{array}$} & \multirow[b]{2}{*}{$\begin{array}{l}\text { Amendment } \\
\text { (rate, wt/wt) }\end{array}$} & \multirow[b]{2}{*}{$\begin{array}{l}\text { Wilt } \\
(\%)^{\mathrm{z}}\end{array}$} & \multicolumn{2}{|c|}{ Plant growth ${ }^{x}$} & \multirow[b]{2}{*}{$\begin{array}{c}\text { Fruit yield } \\
\text { (t/ha) }\end{array}$} \\
\hline & & & $\begin{array}{l}\text { Vine length } \\
\text { (cm) }\end{array}$ & $\begin{array}{l}\text { Dry weight } \\
\text { (g/shoot) }\end{array}$ & \\
\hline \multicolumn{6}{|l|}{2001} \\
\hline \multirow{3}{*}{1} & Nonamended control & $68 \mathrm{a}$ & $108 \mathrm{a}$ & $11 \mathrm{a}$ & $\ldots$ \\
\hline & Hairy vetch $(0.5 \%)$ & $26 \mathrm{~b}$ & $165 \mathrm{~b}$ & $25 \mathrm{~b}$ & $\ldots$ \\
\hline & Hairy vetch $(1 \%)$ & $20 \mathrm{~b}$ & $181 \mathrm{~b}$ & $34 \mathrm{~b}$ & $\ldots$ \\
\hline \multirow[t]{3}{*}{2} & Nonamended control & $60 \mathrm{a}$ & $64 \mathrm{a}$ & $7 \mathrm{a}$ & $\ldots$ \\
\hline & Hairy vetch $(0.5 \%)$ & $20 \mathrm{~b}$ & $112 \mathrm{~b}$ & $14 \mathrm{~b}$ & $\ldots$ \\
\hline & Hairy vetch $(1 \%)$ & $11 \mathrm{~b}$ & $124 \mathrm{~b}$ & $18 \mathrm{c}$ & $\cdots$ \\
\hline \multicolumn{6}{|l|}{2002} \\
\hline \multirow[t]{3}{*}{1} & Nonamended control & $73 \mathrm{a}$ & $96 \mathrm{a}$ & $15 \mathrm{a}$ & $3 \mathrm{a}$ \\
\hline & Hairy vetch $(0.25 \%)$ & $28 \mathrm{~b}$ & $140 \mathrm{~b}$ & $40 \mathrm{~b}$ & $7 \mathrm{ab}$ \\
\hline & Hairy vetch $(0.5 \%)$ & $25 \mathrm{~b}$ & $136 \mathrm{~b}$ & $48 \mathrm{~b}$ & $8 \mathrm{~b}$ \\
\hline \multirow[t]{3}{*}{2} & Nonamended control & $70 \mathrm{a}$ & $107 \mathrm{a}$ & $17 \mathrm{a}$ & $6 \mathrm{a}$ \\
\hline & Hairy vetch $(0.25 \%)$ & $32 \mathrm{~b}$ & $144 \mathrm{~b}$ & $40 \mathrm{ab}$ & $12 \mathrm{~b}$ \\
\hline & Hairy vetch $(0.5 \%)$ & $22 \mathrm{~b}$ & $169 \mathrm{~b}$ & $50 \mathrm{~b}$ & $15 \mathrm{~b}$ \\
\hline
\end{tabular}

${ }^{\mathrm{x}}$ Three plants per microplot were measured for the length of primary runners of plants and were collected for measuring the dry weight of aboveground plant biomass, which both were evaluated 45 days after transplanting for either experiment in 2001 and 51 days after transplanting in 2002. Means followed by the same letter in a column within each experiment are not significantly different $(P \leq$ 0.05 ) according to Fisher's protect least significant difference test. Percent wilt data were analyzed after transformation to the arcsine of the square root of the proportion of wilt; $\ldots=$ not evaluated. All control plants in microplots that received neither Fusarium inoculum nor hairy vetch remained healthy and are not presented in the table.

${ }^{y}$ Microplots were artificially infested with a chlorate-resistant marked isolate culture of Fusarium oxysporum f. sp. niveum. In each year, the second experiment was conducted 2 weeks after the initiation of the first one.

${ }^{\mathrm{z}}$ Average percentage of wilt-susceptible 'Sugar Baby' watermelon (15 plants/microplot, four microplots/amendment) that had one or more runners wilted or dead 45 days after transplanting for either experiment in 2001 and 51 days after transplanting in 2002. 
fold between hairy vetch (965 CFU/g of soil) and 1,3-D + C (55 CFU/g of soil) in 2002, and 23-fold between hairy vetch (1,251 CFU/g of soil) and methyl bromide (55 CFU/g of soil) in 2003. Pathogenicity assays of randomly selected $F$. oxysporum colonies indicated that no differences $(P \geq$ 0.05 ) in the percentage of the $F$. oxysporum f. sp. niveum populations were observed among nontreated control, hairy vetch, and fumigant in each year. This percentage ranged from 53 to $82 \%$ (data not shown). Population densities in plots treated with hairy vetch plus methyl bromide were not different from those in plots treated with methyl bromide alone (Fig. 2).

\section{DISCUSSION}

The results of the current study demonstrated a unique suppression of Fusarium wilt of watermelon by soil amendment with hairy vetch. A significant reduction in the incidence of Fusarium wilt was consistently achieved in greenhouse, microplot, and field experiments. The suppressive effects were comparable to those obtained with the commercially used preplant soil fumigants methyl bromide or 1,3-D + C. Furthermore, the hairy vetch winter cover crop, when incorporated as a green ma-
Table 3. Incidence of Fusarium wilt, plant growth, and marketable fruit yield and sugar content of watermelon in field plots incorporated with hairy vetch winter cover crop compared with preplant chemical soil fumigant in 2002 and $2003^{\vee}$

\begin{tabular}{|c|c|c|c|c|c|}
\hline \multirow[b]{2}{*}{ Year, treatment ${ }^{\mathrm{x}}$} & \multirow[b]{2}{*}{$\begin{array}{l}\text { Wilt } \\
(\%)^{y}\end{array}$} & \multicolumn{2}{|c|}{ Plant growth ${ }^{w}$} & \multicolumn{2}{|c|}{ Marketable fruit } \\
\hline & & $\begin{array}{l}\text { Vine length } \\
\text { (cm) }\end{array}$ & $\begin{array}{c}\text { Dry weight } \\
\text { (g/shoot) }\end{array}$ & $\begin{array}{l}\text { Yield } \\
\text { (t/ha) }\end{array}$ & $\begin{array}{c}\text { Sucrose } \\
(\%)^{\mathrm{z}}\end{array}$ \\
\hline \multicolumn{6}{|l|}{2002} \\
\hline Nontreated control & $46 \mathrm{a}$ & $106 \mathrm{a}$ & $125 \mathrm{a}$ & $38 \mathrm{a}$ & $9.7 \mathrm{a}$ \\
\hline $1,3-\mathrm{D}+\mathrm{C}$ & $26 \mathrm{~b}$ & $112 \mathrm{a}$ & $257 \mathrm{~b}$ & $57 \mathrm{~b}$ & $9.8 \mathrm{a}$ \\
\hline Hairy vetch & $24 \mathrm{~b}$ & $129 \mathrm{~b}$ & $205 \mathrm{~b}$ & $51 \mathrm{~b}$ & $10.7 \mathrm{~b}$ \\
\hline \multicolumn{6}{|l|}{2003} \\
\hline Nontreated control & $36 \mathrm{a}$ & $149 \mathrm{a}$ & $110 \mathrm{a}$ & $25 \mathrm{a}$ & $10.3 \mathrm{a}$ \\
\hline MB & $17 \mathrm{~b}$ & $163 \mathrm{~b}$ & $190 \mathrm{~b}$ & $45 \mathrm{~b}$ & $10.8 \mathrm{a}$ \\
\hline Hairy vetch & $21 \mathrm{~b}$ & $157 a b$ & $220 b c$ & $42 \mathrm{~b}$ & $11.8 \mathrm{~b}$ \\
\hline Hairy vetch $+\mathrm{MB}$ & $15 \mathrm{~b}$ & $182 \mathrm{c}$ & $235 \mathrm{c}$ & $38 \mathrm{~b}$ & $11.4 \mathrm{~b}$ \\
\hline
\end{tabular}

${ }^{\mathrm{v}}$ Means followed by the same letter in a column within each year are not significantly different $(P \leq$ $0.05)$ according to Fisher's protected least significant difference test. Percent wilt data were analyzed after transformation to the arcsine of the square root of the proportion of wilt.

${ }^{w}$ Three plants per plot were measured 21 days after transplanting for the length of primary runners of plants and were collected at fruit harvest for measuring the dry weight of aboveground plant biomass in each year.

${ }^{\mathrm{x}}$ Hairy vetch was incorporated into soil as a green manure at the estimated aboveground dry matter rates of $5.2 \mathrm{t} / \mathrm{ha}$ in 2002 and $4.4 \mathrm{t} / \mathrm{ha}$ in 2003 ; 1,3-dichloropropene plus $35 \%$ chloropicrin $(1,3-D+C$; Telone C35) was injected into winter fallow soil at 327 liter/ha, and methyl bromide (MB, Terr-O-Gas 98) was injected into winter fallow soil or hairy vetch-amended soil at $224 \mathrm{~kg} / \mathrm{ha}$.

y Average percentage of 'Sangria' watermelon (moderately susceptible to race 1 of Fusarium oxysporum f. sp. niveum; 28 plants/plot, 4 plots/treatment) that had one or more runners wilted or dead 56 and 60 days after transplanting in 2002 and 2003, respectively.

${ }^{\mathrm{z}}$ Average of four plots of three fruit each.
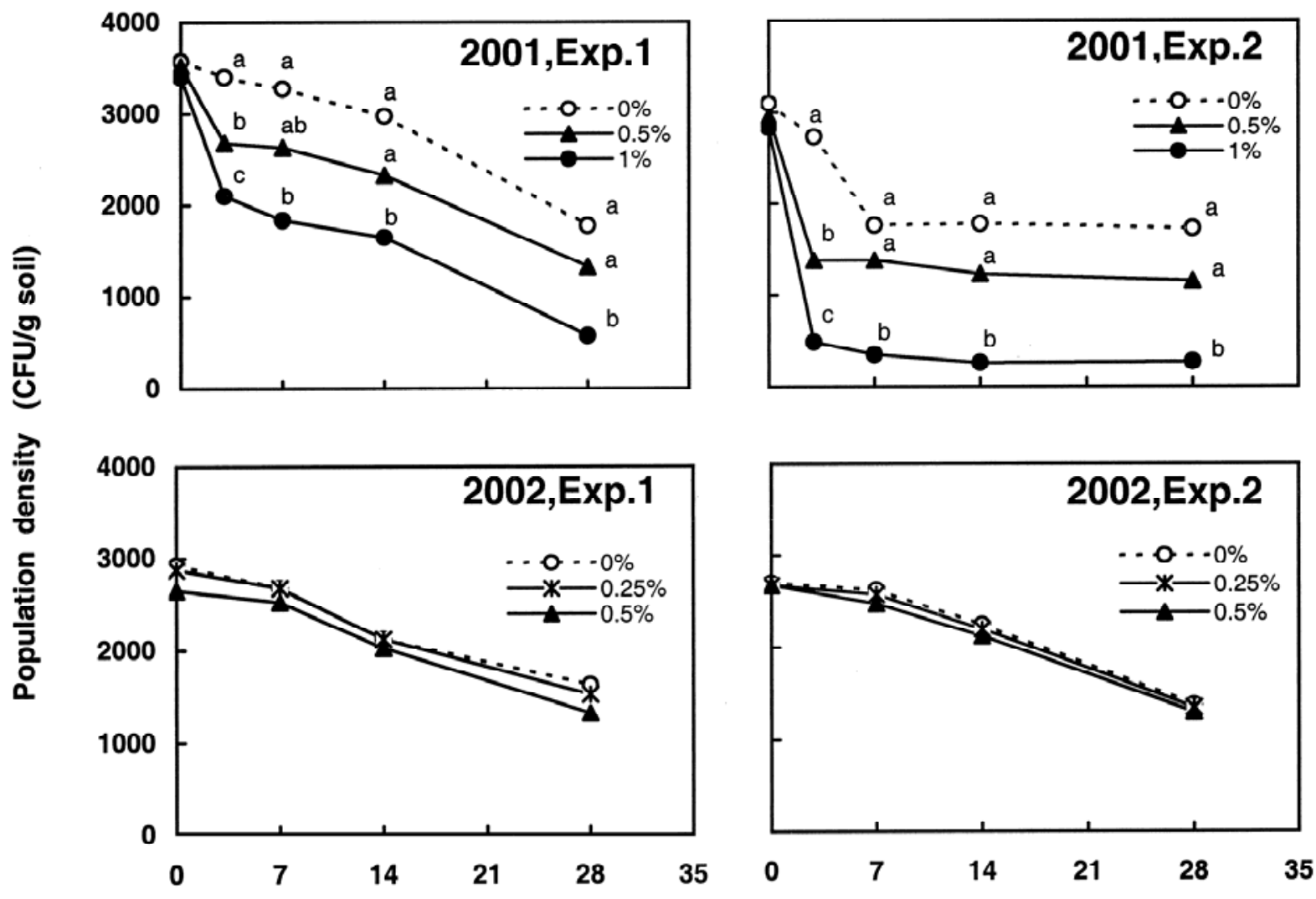

Days after amendment

Fig. 1. Population densities of Fusarium oxysporum f. sp. niveum in field microplots after amendment of hairy vetch at three rates $(0,0.25,0.5$, or $1 \%$; $\mathrm{wt} / \mathrm{wt}$ ) in each of two experiments in 2001 and 2002. Microplots were artificially infested with a chlorate-resistant marked isolate culture of $F$. oxysporum f. sp. niveum, and population densities were determined by soil dilution plating on a chlorate-resistant selective medium. Each point was the mean of four replicate microplots of two plates each. Points followed by the same letter at each date are not significantly different $(P \leq 0.05)$ according to Fisher's protected least significant difference test. Data were transformed to $\log _{10}(\mathrm{CFU} / \mathrm{g}$ of soil +1$)$ prior to analysis. There were no significant differences $(P \geq 0.05)$ in population density at each date evaluated in each experiment in 2002. 
nure, increased not only marketable fruit yield but fruit sugar content as well, whereas the fumigants had a benefit only on fruit yield increase. However, observed wilt suppression, growth promotion, and yield improvement in hairy vetch-amended plots were not associated with a significant reduction in soil populations of $F$. $o x$ ysporum f. sp. niveum.

For the first time, we have found that a soil amended with hairy vetch may induce suppressiveness to Fusarium wilt. Previously, incorporation of hairy vetch cover crop into a loam soil in Arkansas was shown to suppress the incidence of cotton disease caused by $T$. basicola (31), isolation frequency of the fungus from cotton seedlings (31), and soil populations of this pathogen $(4,5,31)$. When used as an organic mulch in Maryland, no-tilled hairy vetch was reported to reduce the severity of the four foliar fungal diseases: powdery mildew (caused by Podosphaera xanthii) and Plectosporium blight (by Plectosporium tabacinum) on pumpkin (10), and early blight (by Alternaria solani) and Septoria leaf spot (by Septoria lycopersici) on staked fresh market tomato (23). In addition, the suppressive effects of urea and crab shell on soil populations of various formae speciales of $F$. oxysporum that were observed in previous studies $(33,34,36,39)$ also were confirmed in our greenhouse experiments. We further evaluated the effects of urea and crab shell soil amendments on suppression of Fusarium wilt under field conditions. The results of that study will be reported in a separate communication.

Urea and other soil amendments can cause an increase in the level of ammonia, which is fungicidal to a wide spectrum of soilborne pathogens $(6,32-34,38,40)$, often resulting in a significant reduction in soil pathogen populations. We observed a negative linear relationship between ammonia level and inoculum density of $F$. oxysporum f. sp. niveum. Production of suppressive amounts of ammonia has been one of the most postulated mechanisms for suppression of soilborne pathogens and diseases in organic-amended soils $(4,6,32-$ 34,40). This also is the mechanism by which hairy vetch suppressed $T$. basicola (4). Smiley et al. (34) reported that 200 ppm of ammonia generated from urea for $24 \mathrm{~h}$ was sufficient to reduce germination of the chlamydospores of $F$. roseum $\mathrm{f}$. sp. cerealis. Therefore, in our greenhouse experiments, suppression of Fusarium wilt in watermelon by hairy vetch at $5 \%$ (wt/wt) could be due in part to the generation of ammonia ( $\geq 140 \mathrm{ppm}$ ) that led to 66 to $78 \%$ reduction in soil propagules of $F$. oxysporum f. sp. niveum, comparable to the reductions (66 to 100\%) obtained with soil amendment of 0.1 or $0.5 \%$ urea. In contrast, the addition of hairy vetch at the lower rate $(1 \%)$ appeared to produce insufficient concentrations of ammonia to sig- nificantly reduce soil populations. However, the observed levels of wilt suppression by the lower rate were equal to or even greater than those obtained with $0.1 \%$ urea. These results indicate that the production of ammonia is unlikely to be the sole mechanism responsible for wilt suppression by soil amendment with hairy vetch and that other unidentified mechanisms of action may be involved. This explanation is further supported by the results from our microplot and field experiments, in which hairy vetch at rates below $0.5 \%$ suppressed Fusarium wilt but not soil populations of $F$. oxysporum $\mathrm{f}$. sp. niveum. Investigation is underway to elucidate the mechanism or mechanisms of hairy vetch-induced wilt suppression.

Chicken manure, oyster shell, and soybean, which previously were shown to be effective in suppressing some soilborne pathogens $(14,36,37,39,40)$, were ineffective or inconsistent for suppression of Fusarium wilt of watermelon in two types of soil evaluated in this study. This result suggested that efficacy of organic amendments may vary with soil type, source and production of amendment, and host-pathogen system.

The relationship between soil $\mathrm{pH}$ and ammonia level observed in this study was

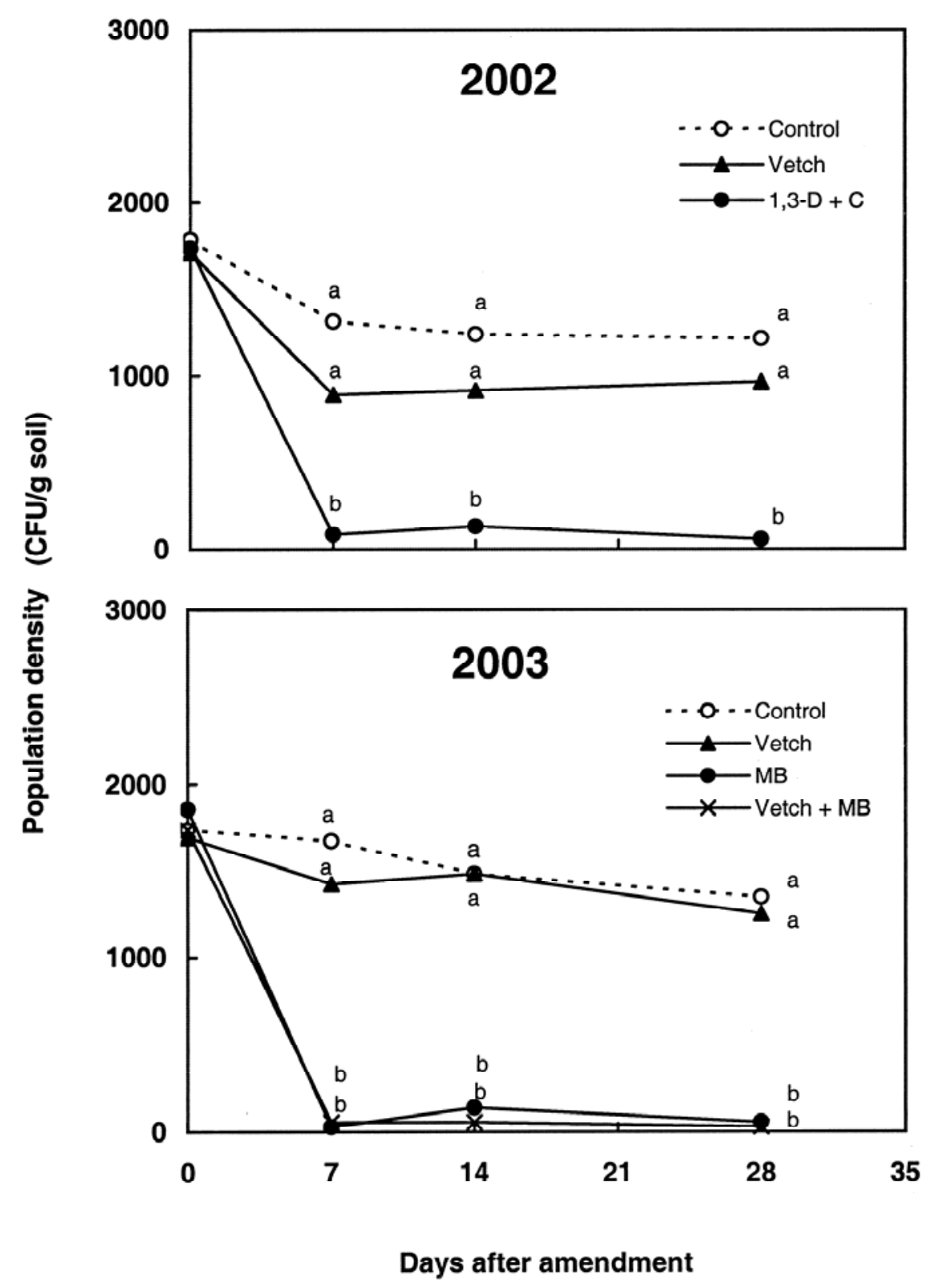

Fig. 2. Population densities of Fusarium oxysporum f. sp. niveum in field plots after incorporation of hairy vetch winter cover crop compared with the preplant soil fumigants 1,3-dichloropropene plus $35 \%$ chloropicrin (1,3-D + C; 327 liter/ha) or methyl bromide (MB; $224 \mathrm{~kg} / \mathrm{ha})$ in 2001 and 2002. Population densities were determined by soil dilution plating on Komada's medium and adjusted by additional greenhouse pathogenicity bioassays of randomly selected representative colonies of $F$. oxysporum. Each point was the mean of four replicate plots of two plates each. Points followed by the same letter at each date are not significantly different $(P \leq 0.05)$ according to Fisher's protected least significant difference test. Data were transformed to $\log _{10}(\mathrm{CFU} / \mathrm{g}$ of soil +1$)$ prior to analysis. 
consistent with previous observations that the concentrations of ammonia in the soil depended on $\mathrm{pH}$ and that increased $\mathrm{pH}$ levels at 7 or above in amended soil provided more favorable conditions for the formation of ammonia $(9,37)$. High soil $\mathrm{pH}$ usually favors activity of some soil microorganisms, especially bacteria that decompose organic substances (26).

Increase in organic matter and nutrients as well as improved physical and chemical properties of soil are other benefits of using a hairy vetch cover crop. Estimates of immediate nitrogen $(\mathrm{N})$, phosphorus $(\mathrm{P})$, and potassium $(\mathrm{K})$ contributions from a hairy vetch cover crop for a subsequent watermelon crop ranged from 67 to 80,8 to 10 , and 48 to $57 \mathrm{~kg} / \mathrm{ha}$, respectively, for hairy vetch aboveground biomass measured in the current field studies (1). Incorporation of hairy vetch also increases other minor nutrients required for watermelon growth and improves soil properties, including increased water retention and water infiltration rate, and saturated hydraulic conductivity (1). Those benefits, especially increase in $\mathrm{N}$, at least partially account for improved plant growth and fruit sugar content in hairy vetch-amended plots.

Hairy vetch, when amended to soils at $1 \%$ (wt/wt), significantly reduced propagules of $F$. oxysporum f. sp. niveum in microplot tests but not in greenhouse tests. The differences in the responses of soil population probably are due to increased temperatures under field conditions. An increased maximum soil temperature up to $41^{\circ} \mathrm{C}$ under plastic film was observed in hairy vetch-amended microplots and may have reduced pathogen survival $(11,21)$. This may partially explain the downward trend in the populations of $F$. oxysporum $\mathrm{f}$. sp. niveum in either nonamended soil or hairy vetch-amended soil in both microplot and field experiments. Hairy vetch soil amendment, along with increased temperatures under plastic film, also had an additional benefit of suppressing the growth of some annual grass and broadleaf weeds observed in our microplot tests (46). Solarization alone or in combination with organic amendments has been an effective method of controlling fungi, weeds, and other pests under suitable climatic conditions $(11,15,16,21,29)$.

Substantial reductions in wilt incidence by hairy vetch were observed at rates as low as $0.25 \%$ in microplot tests and at about $0.2 \%$ (wt/wt) in field tests, indicating that soil amendment with hairy vetch may be a practical approach against Fusarium wilt of watermelon. Such low effective rates can be obtained under a wide range of climatic conditions (1). Another benefit of the low amendment rates is the reduction of potential phytotoxicity to host plants due to the large amounts of ammonia or other gases that may be released from soil amendments. As an example, minor phytotoxicity from the high rates (5 and $1 \%$ ) of hairy vetch addition was observed in our greenhouse and microplot tests, respectively. Phytotoxicity is regarded as a potential obstacle to the use of organic amendments, especially at extremely high rates (9).

The use of wilt-resistant cultivars and crop rotations continues to be the primary means of managing Fusarium wilt of watermelon. Using hairy vetch as a green manure may serve as a new, potential alternative or supplement to these control methods. Hairy vetch soil amendment has few human and environmental risks and is compatible with current crop production systems in the mid-Atlantic United States and other regions; therefore, it could be used in organic crop production systems. It also could be adopted as one of the principal components in an integrated management system for the control of multiple pests in conventional production systems. However, more work is needed to verify the efficacy of hairy vetch soil amendment in various types of soil, and to identify the conditions in which wilt suppressiveness occurs. Further studies also are needed to explore the effects of hairy vetch soil amendment on Fusarium wilts in other economically important agricultural crops.

\section{ACKNOWLEDGMENTS}

We thank D. K. Armentrout for technical assistance, L. E. Carr for providing composted organic materials and assistance in preparation and grinding of organic materials, and anonymous referees for review that improved the text.

\section{LITERATURE CITED}

1. Bowman, G., Shirley, C., and Cramer, C. 1998. Managing Cover Crops Profitably. Sustainable Agriculture Network, Washington, DC.

2. Bruton, B. D., and Damicone, J. P. 1999. Fusarium wilt of watermelon: Impact of race 2 of Fusarium oxysporum f. sp. niveum on watermelon production in Texas and Oklahoma. Subtrop. Plant Sci. 51:4-9.

3. Bruton, B. D., Patterson, C. L., and Martyn, R. D. 1988. Fusarium wilt (F. oxysporum f. sp. niveum race 2) of watermelon in Oklahoma. Plant Dis. 72:734.

4. Candole, B. L., and Rothrock, C. S. 1997. Characterization of the suppressiveness of hairy vetch-amended soils to Thielaviopsis basicola. Phytopathology 87:197-202.

5. Candole, B. L., and Rothrock, C. S. 1997. Using marked strains to assess the effect of hairy vetch amendment on the inoculum densities of Thielaviopsis basicola, Pythium ultimum and Rhizoctonia solani. Soil Biol. Biochem. 30:443-448.

6. Chun, D., and Lockwood, J. L. 1985. Reductions of Pythium ultimum, Thielaviopsis basicola, and Macrophomina phaseolina populations in soil associated with ammonia generated from urea. Plant Dis. 69:154-158.

7. Cirulli, M. 1972. Variation of pathogenicity in Fusarium oxysporum f. sp. niveum and resistance in watermelon cultivars. Pages 491-500 in: Actas III Congr. Union Fitopathol. Mediterr. Oeiras, Portugal.

8. Cook, R. J., and Baker, K. F. 1983. The Nature and Practice of Biological Control of Plant Pathogens. American Phytopathological Society, St. Paul, MN

9. Ells, J. E., McSay, A. E., and Workman, S. M. 1991. Toxic effects of manure, alfalfa, and ammonia on emergence and growth of cucumber seedlings. HortScience 26:380-383.

10. Everts, K. L., 2002. Reduced fungicide applications and host resistance for managing three diseases in pumpkin grown on a no-till cover crop. Plant Dis. 86:1134-1141.

11. Gonzalez-Torres, R., Melero-Vara, J. M. Gomez-Vazquez, J., and Jimenez Diaz, R. M. 1993. The effects of soil solarization and soil fumigation on Fusarium wilt of watermelon grown in plastic houses in south-eastern Spain. Plant Pathol. 42:858-864.

12. Hadar, E., Katan, J., and Katan, T. 1989. The use of nitrate-nonutilizing mutants and a selective medium for studies of pathogenic strains of Fusarium oxysporum. Plant Dis. 73:800803.

13. Hopkins, D. L., and Elmstrom, G. W. 1984. Effect of nonhost crop plants on watermelon Fusarium wilt. Plant Dis. 68:239-241.

14. Huber, D. M., and Watson, R. D. 1970. Effect of organic amendment on soil-borne plant pathogens. Phytopathology 60:22-26.

15. Katan, J. 1981. Solar heating (solarization) of soil for control of soilborne pests. Annu. Rev. Phytopathol. 19:211-236.

16. Keinath, A. P. 1996. Soil amendment with cabbage residue and crop rotation to reduce gummy stem blight and increase growth and yield of watermelon. Plant Dis. 80:564-570.

17. Komada, H. 1975. Development of selective medium for quantitative isolation of Fusarium oxysporum from natural soil. Rev. Plant Prot. Res. 9:114-125.

18. Martyn, R. D. 1987. Fusarium oxysporum f. sp. niveum race 2: A highly aggressive race new to the United States. Plant Dis. 71:233236.

19. Martyn, R. D. 1996. Fusarium wilt of watermelon. Pages 13-14 in: Compendium of $\mathrm{Cu}$ curbit Diseases. T. A. Zitter, D. L. Hopkins, and C. E. Thomas, eds. The American Phytopathological Society, St. Paul, MN.

20. Martyn, R. D., and Bruton, B. D. 1989. An initial survey of the United States for races of Fusarium oxysporum f. $\mathrm{sp}$. niveum HortScience 24:696-698.

21. Martyn, R. D., and Hartz, T. K. 1986. Use of soil solarization to control Fusarium wilt of watermelon. Plant Dis. 70:762-766.

22. Martyn, R. D., and McLaughlin, R. J. 1983. Effects of inoculum concentration on the apparent resistance of watermelon to Fusarium oxysporum f. sp. niveum. Plant Dis. 67:493495.

23. Mills, D. L., Coffman, C. B., Teasdale, J. R., Everts, K. L., and Anderson, J. D. 2002. Factors associated with foliar disease of staked fresh market tomatoes grown under differing bed strategies. Plant Dis. 86:356-361.

24. Muehlchen, A. M., Rand, R. E., and Parker, J. L. 1990. Evaluation of crucifer green manures for controlling Aphanomyces root rot of peas. Plant Dis. 74:651-654.

25. Netzer, D. 1976. Physiological races and soil population level of Fusarium wilt of watermelon. Phytoparasitica 4:131-136.

26. Opgenorth, D. C., and Endo, R. M. 1983. Evidence that antagonistic bacteria suppress Fusarium wilt of celery in neutral and alkaline soils. Phytopathology 73:703-708.

27. Paulus, A. O., Harvey, O. A., Nelson, J., and Shibuya, F. 1976. Fusarium-resistant watermelon cultivars. Calif. Agric. 30:5-6.

28. Puhalla, J. E. 1985. Classification of strains of Fusarium oxysporum on the basis of vegetative incompatibility. Can. J. Bot. 63:179-183.

29. Ramirez-Villapudua, J., and Munnecke, D. E. 1987. Control of cabbage yellows (Fusarium oxysporum f. sp. conglutinans) by solar heating of field soils amended with dry cabbage residues. Plant Dis. 71:217-221.

30. Ramirez-Villapudua, J., and Munnecke, D. E. 1988. Effect of solar heating and soil amendments of cruciferous residues on Fusarium ox- 
ysporum $\mathrm{f}$. sp. conglutinans and other organisms. Phytopathology 78:289-295.

31. Rothrock, C. S., and Kirkpatrick, T. L., Frans, R. E., and Scott, H. D. 1995. The influence of winter legume cover crops on soilborne plant pathogens and cotton seedling diseases. Plant Dis. 79:167-171.

32. Schippers, B., and Palm, L. C. 1973. Ammonia, a fungistatic volatile in chin-amended soil. Neth. J. Plant Pathol. 79:279-281.

33. Sequeira, L. 1963. Effect of urea applications on survival of Fusarium oxysporum f. cubense in soil. Phytopathology 53:332-336.

34. Smiley, R. W., Cook, R. J., and Papendick, R. I. 1970. Anhydrous ammonia as a soil fungicide against Fusarium and fungicidal activity in the ammonia retention zone. Phytopathology 60:1227-1232.

35. Subbarao, K. V., Hubbard, J. C., and Koike, S. T. 1999. Evaluation of broccoli residue incorporation into field soil for Verticillium wilt control in cauliflower. Plant Dis. 83:124-129.

36. Sun, S. K., and Huang, J. W. 1985. Formulated soil amendment for controlling Fusarium wilt and other soilborne diseases. Plant Dis. 69:917-920.

37. Taso, P. H., and Oster, J. J. 1981. Relation of ammonia and nitrous acid to suppression of Phytophthora in soils amended with nitrogenous organic substances. Phytopathology 71:53-59.

38. Warren, K. S. 1962. Ammonia toxicity and pH. Nature 195:47-49.

39. Zakaria, M. A., and Lockwood, J. L. 1980. Reduction in Fusarium populations in soil by oilseed meal amendments. Phytopathology 70:240-243.

40. Zakaria, M. A., Lockwood, J. L., and Filonow, A. B. 1980. Reduction in Fusarium population density in soil by volatile degradation products of oilseed meal amendments. Phytopathology 70:495-499.

41. Zhou, X. G., and Everts, K. L. 2001. First report of the occurrence of Fusarium oxysporum f. sp. niveum race 2 in commercial watermelon production areas of Maryland and Delaware. Plant Dis. 85:1291.

42. Zhou, X. G., and Everts, K. L. 2002. Hairy vetch soil amendment: A new potential alternative for suppression of Fusarium wilt in watermelon. (Abstr.) Phytopathology 92:S91.

43. Zhou, X. G., and Everts, K. L. 2003. Races and inoculum density of Fusarium oxysporum f. sp. niveum in commercial watermelon fields in Maryland and Delaware. Plant Dis. 87:692698.

44. Zhou, X. G., Everts, K. L., and Armentrout, D. K. 2003. Evaluation of seedless (triploid) watermelon cultivars for resistance to Fusarium wilt, 2002. Biol. Cult. Tests (online) 18:V003. DOI:10:1094/BC18.

45. Zhou, X. G., Everts, K. L., and Armentrout, D. K. 2003. Hairy vetch and urea soil amendments: A novel strategy for management of Fusarium wilt in watermelon, 2002. Biol. Cult. Tests (online) 18:V006. DOI:10:1094/BC18.

46. Zhou, X. G., Everts, K. L., and VanGessel, M. J. 2003. Effects of soil amendment rates of hairy vetch and urea on suppression of watermelon Fusarium wilt and annual weeds, 2002. Biol. Cult. Tests (online) 18:V005 DOI:10:1094/BC18. 